\title{
Population dynamics and stock assessment of Delegoa threadfin bream, Nemipterus bipunctatus (Nemipteridae), from the Wadge Bank, South India
}

\author{
K. Karuppasamy ${ }^{1 *}$, S. David Kingston ${ }^{2}$, P. Jawahar ${ }^{1}$, S.Aanand ${ }^{1}$, V.K.Venkataramani ${ }^{3}$ \\ and V.Vidhya ${ }^{1}$
}

${ }^{1}$ Fisheries College and Research Institute, TNFU, Tuticorin (Tamil Nadu), INDIA

${ }^{2}$ Fisheries Training and Research Centre, TNFU, Parakkai, Kanyakumari (Tamil Nadu), INDIA

${ }^{3}$ Kerala University of Fisheries and Ocean Studies, Panangad, Kochi (Kerala), INDIA

*Corresponding author. E-mail: karuppasamymfsc@gmail.com

Received: January 10, 2017; Revised received: August 14, 2017; Accepted: January 10, 2018

\begin{abstract}
Fishery, population characteristics and stock estimates of Nemipterus bipunctatus were studied during June 2015 to May 2016 from Wadge Bank, South India. This region is characterised by rich biodiversity and has a conducive influence of the Indian Ocean and Arabian Sea. The asymptotic length $(L \infty)$, growth coefficient $(K)$ and arbitrary origin of growth $\left(\mathrm{t}_{0}\right)$ were estimated as $30.5 \mathrm{~cm}, 0.85 /$ year and 0.18 respectively. The mortality parameters, total mortality rate $(Z)$, fishing mortality rate and natural mortality rate $(\mathrm{M})$ were estimated as $2.20,0.95$ and 1.25 respectively. Exploitation ratio $(E)$ was found to be 0.57 which showed marginal over exploitation of the species at Wadge Bank. This species has two recruitment seasons, one major season from October to December and another minor season in August. The length structured Virtual population analysis revealed heavy fishing pressure on the length group 24 to $28 \mathrm{~cm}$ and hence the delegoa threadfin bream was not found to suffer due to recruitment overfishing in Wadge Bank. Estimated total stock, Maximum Sustainable Yield (MSY) and annual catch were 5625.9348 tonnes, 1935.321t, 2419.152t respectively. Present level of Exploitation rate $(U)$ and Exploitation ratio (F/Z) were estimated to be 0.43 and 0.57 respectively. The study infers the cod end mesh size of the trawls operated at Wadge Bank coast has to be increase from 10 to $25 \mathrm{~mm}$ to increase the yield per recruit, the effort could also be maintained as the exploitation ratio of 0.50 to have maximum yield per recruit. The study suggests reducing the present level of effort by 8 percent may be needed to sustain the stock of $N$. bipunctatus in Wadge Bank, South India.
\end{abstract}

Keywords: Growth, Mortality parameters, MSY, Nemipterus bipunctatus, Recruitment overfishing

\section{INTRODUCTION}

The threadfin breams (Nemipteridae) are small to medium-sized marine fishes spread in the tropical and subtropical Indo-West Pacific region, but absent in the eastern Pacific and Atlantic oceans (Russell, 1990). They represent a significant component of demersal fish communities and are important to fisheries throughout the Indo-West Pacific (Pauly and Martosubroto, 1980; Russell, 1990; Harris and Poiner, 1990; Sharum, 2002). A total of six species, Nemipterus japonicus, $N$. mesoprion, $N$. tolu, $N$. delagoae ( $N$. bipunctatus), N. Luteus and N. metopias, contributed to the fishery along Indian coast. Of these, the first two species contributed to the fishery significantly all along the Indian coast, whereas $N$. bipunctatus form a moderate fishery along the Wadge Bank, South India (Murty, 1992). Although several studies have been made on the stock estimates of threadfin breams from India (Murty, 1983, 1984, 1987; Vivekanandan and James, 1986; Devaraj and Gulati, 1988; John, 1989, Joshi, 2010 and Swatipriyankasen 2014) Information on catch, effort, growth parameters and biology of $N$. bipunctatus from Indian waters are available from the studies of Muthiah and Pillai 1979; Madanmohan and Velayudhan, 1986 and Hamsa et al.(1994). The present study on the stock assessment of $N$. bipunctatus, is the first of its kind in Indian waters, attempted from Wadge Bank, South India.

\section{MATERIALS AND METHODS}

The study was carried out for a period of 12 months from June 2015 to May 2016. Length frequency data were collected two times in a month for $N$. bimaculatus to estimate the age, growth and mortality parameters. A total of 2,246 specimens of $N$. bimaculatus were collected mainly from mechanised and motorized fish landing centres along Wadge Bank coast during the 12 months study period (Fig.1). Age and growth were assessed using the FiSAT computer software (Gayanilo et al., 1996). Length frequency data of $N$. bipunctatus were recorded every week. About 300 specimens were collected during every sampling and 
the total length and the weight of each specimen were measured and recorded. Age and growth was assessed using FiSAT computer software. The $\mathrm{L} \infty$ and $\mathrm{k}$ values were analysed by non-parametric scoring of VBGF fit using ELEFAN-1.The length frequency data were subjected to model progression technique by splitting the modes using Bhattachary's analysis followed by linking of the means. To assess the standing stock, total annual stock, maximum sustainable yield, and to optimize the effort, catch effort data were collected. The mean catch of $N$. bipunctatus were recorded from $10 \%$ of the fishing boats in a fishing day and was multiplied with effort made in trawling hours in the days of observation to obtain the estimates. The daily catch estimates were used to estimate the monthly mean catch which was multiplied by the no of fishing days of the corresponding month to obtain the monthly catch. Total effort in boat days was estimated by multiplying the mean monthly effort expressed in boat days which is the fishing days in a month.

The total mortality rate $(Z)$ was estimated by the length converted catch curve method using FiSAT. The natural mortality $(\mathrm{M})$ was estimated by pauly equation considering the mean annual temperature. The co-efficient of fishing mortality $(\mathrm{F})$ was derived using the relationship $\mathrm{Z}=\mathrm{F}+\mathrm{M}$. The length structured VPA of FiSAT was used to find out the size of each length group $N$. bipunctatus, their natural mortality and fishing mortality. Recruitment pulses of $N$. bipunctatus were analysed from the length frequency data using FiSAT. The total stock $(\mathrm{Y} / \mathrm{U})$ and the annual $\operatorname{stock}(\mathrm{Y} / \mathrm{F})$ were estimated for $N$. bipunctatus using annual catch (Y). Where, Y Yield, U - exploitation rate and F - Fishing mortality. The exploitation rate (U) was estimated using the equation $\mathrm{U}=\mathrm{F} / \mathrm{Z}\left(1-\mathrm{e}^{-\mathrm{z}}\right)$ (Sparre and venema,1998). The Maximum Sustainable Yield (MSY) was estimated using the equation $\mathrm{MSY}=\mathrm{Z}(\mathrm{Y} / \mathrm{F}) 0.5$ described by Gulland (1979). Yield isopleth diagrams of $N$. bipunctatus were derived by FiSAT using L50/L $\infty$ and $\mathrm{F} / \mathrm{Z}$ value.

\section{RESULTS AND DISCUSSION}

In the present study multiple modes could be seen in

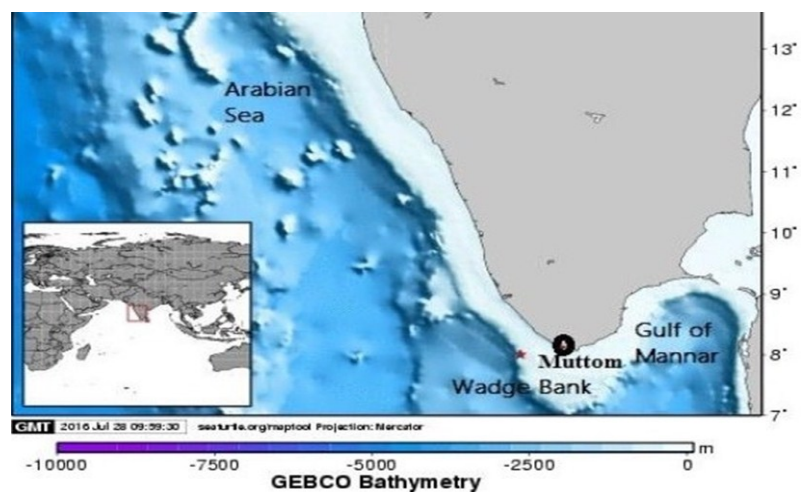

Fig.1. Map showing the study area of Wadge bank ( Source, online GIS program MAPTOOL, provided by seaturtle.org).

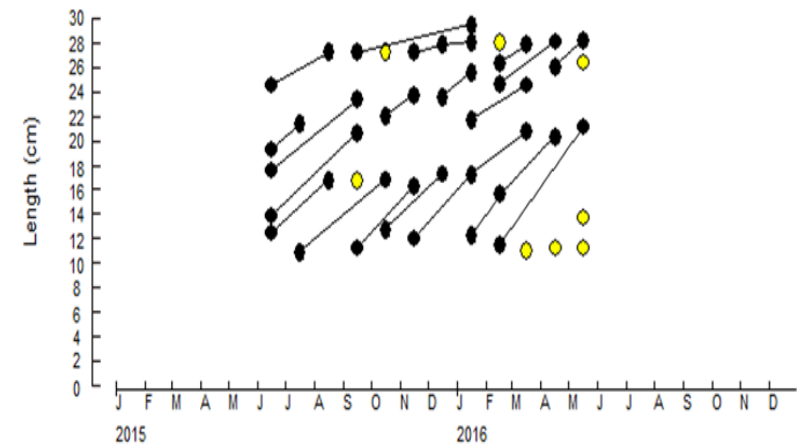

Fig. 2. Progression of modes of various cohorts of N. bipunctatus.

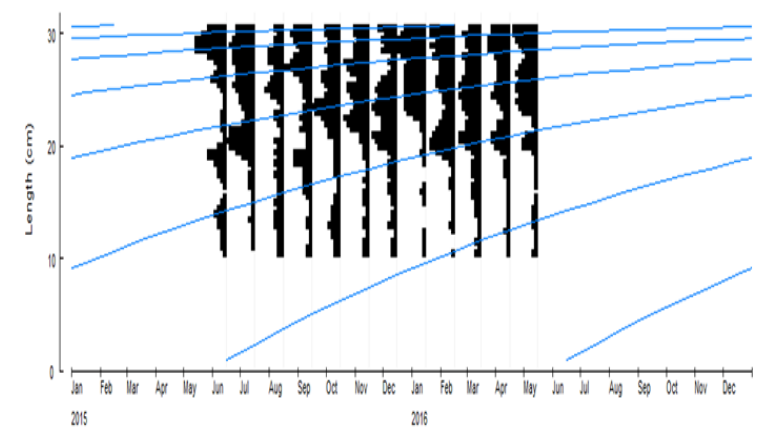

Fig. 3. Von Bertalanffy's growth function plot of N. bipunctatus.

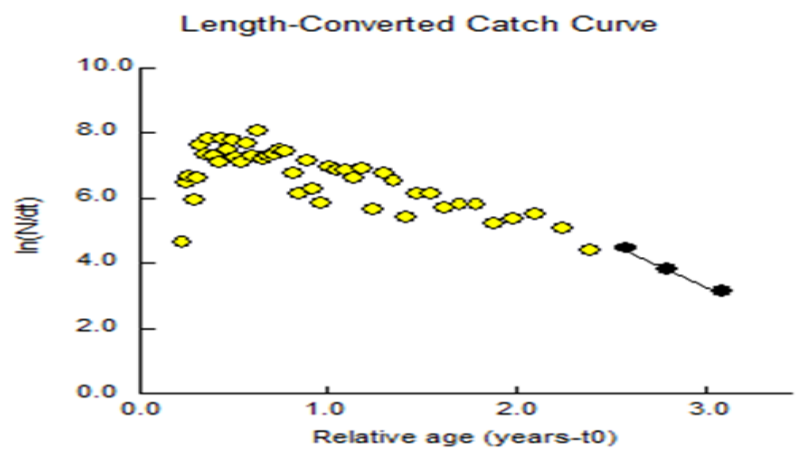

Fig. 4. Length based catch curve of N. bipunctatus.

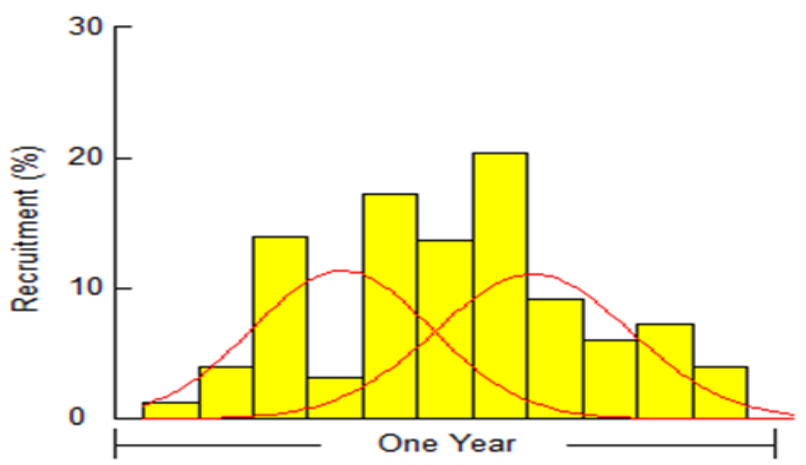

Fig.5. Recruitment pattern of $N$. bipunctatus.

Table.1. Growth parameters of $N$. bipunctatus of Wadge bank.

\begin{tabular}{lllll}
\hline Species & $\mathbf{L} \infty \mathbf{( c m )}$ & $\mathbf{K}$ & $\mathbf{M} / \mathbf{K}$ & $\mathbf{t}_{\mathbf{0}}$ \\
\hline N. bipunctatus & 30.5 & 0.85 & 1.12 & 0.18 \\
\hline
\end{tabular}




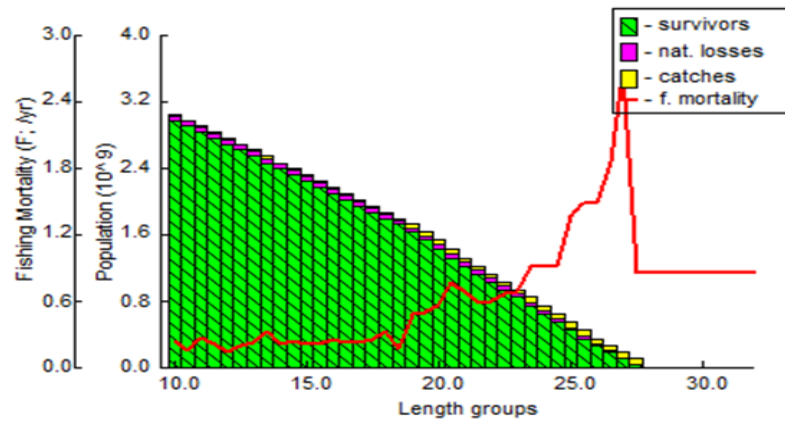

Fig. 6. Virtual population analysis.

the monthly length frequency data and modes were traceable. At least for two consecutive month to assess the growth of cohorts (Fig. 2). The maximum life span was found to be 5 years for $N$. bipunctatus. The Bertalanffy's Growth Function plot of $N$. bipunctatus are represented in Figure 3.

The estimated growth parameters of $N$. bipunctatus are shown in Table.1. The asymptotic length $(\mathrm{L} \infty)$, growth co-efficient $(\mathrm{K})$, were $30.5 \mathrm{~cm}$ and 0.85 respectively. Similarly, Hamsa et al.(1994) estimated the growth parameters from length data of $N$. delagoae landed at Thoothukudi were, $\mathrm{L} \infty,=362 \mathrm{~mm}$ and $\mathrm{K}=1.0586$ per
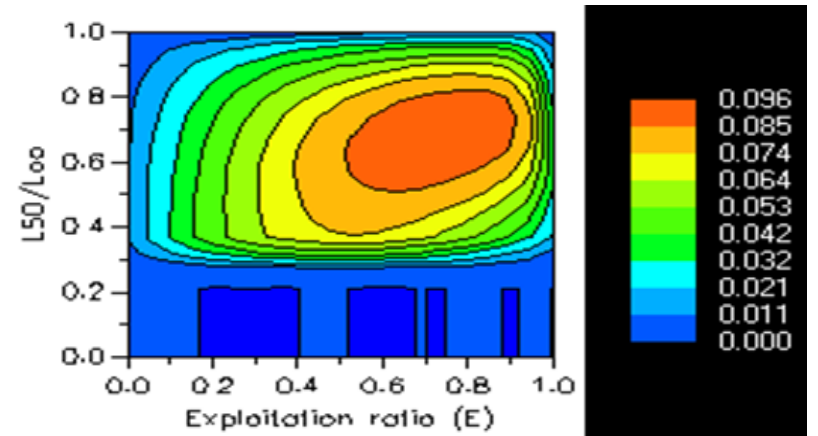

Fig.7. Yield isopleths of N. bipunctatu.s

year which had higher than that recorded in the present study. The factors explaining the relationship between the natural mortality coefficient and growth coefficient (M/K) was 2.00 for $N$. bipunctatus. The generalized von Bertalanffy;s growth equation for $N$. bipunctatus are given below; $\mathrm{L}(\mathrm{t})=30.5\{1-\exp -0.85(\mathrm{t}-0.18)-(1)$.

Mortality, virtual population analysis and recruitment pattern parameters: The mortality parameters and exploitation ratio of $N$. bipunctatus are shown in Table. 2. The natural mortality (M) of $N$. bipunctatus were found to be 0.95 . The fishing mortality coefficient (F) of $N$. bipunctatus were 1.25. The estimate

Table.2. Mortality parameters and exploitation ratio of $N$. bipunctatus of Wadge Bank, South India.

\begin{tabular}{|c|c|c|c|c|c|c|}
\hline Species & $\begin{array}{l}\text { Natural } \\
\text { (M) }\end{array}$ & Mortality & $\begin{array}{l}\text { Fishing } \\
\text { (F) }\end{array}$ & mortality & $\begin{array}{l}\text { Total instantaneous mor- } \\
\text { tality }(\mathrm{Z})\end{array}$ & $\begin{array}{l}\text { Exploitation ratio }(\mathrm{E} \\
=\mathrm{F} / \mathrm{Z})\end{array}$ \\
\hline$N$. bipunctatus & 0.95 & & 1.25 & & 2.20 & 0.57 \\
\hline
\end{tabular}

Table.3. Exploitation rate, total stock and annual stock of $N$. bipunctatus inWadge Bank.

\begin{tabular}{|c|c|c|c|c|c|c|}
\hline Species & $\begin{array}{l}\begin{array}{l}\text { Annual catch (Y) } \\
\text { (tonnes) }\end{array} \\
\end{array}$ & Exploitation rate (U) & $\begin{array}{l}\text { Total stock } \\
\text { (Y/U) }\end{array}$ & $\begin{array}{l}\begin{array}{l}\text { Annual } \\
\text { (tonnes) }\end{array} \\
\end{array}$ & stock & $(\mathbf{Y} / \mathbf{F})$ \\
\hline N. bipunctatus & 2419.152 & 0.43 & 5625.9348 & 1935.321 & & \\
\hline
\end{tabular}

Table 4. Optimum effort for the exploitation of N. bipunctatus of Wadge bank, South India.

\begin{tabular}{|c|c|c|c|c|c|c|c|c|}
\hline Species & $\begin{array}{l}\text { Catch } \\
\text { (tonnes) }\end{array}$ & $\begin{array}{l}\text { MSY } \\
\text { (tonnes) }\end{array}$ & $\begin{array}{l}\text { Different } \\
\text { between } \\
\text { catch and } \\
\text { MSY } \\
\text { (tonnes) } \\
\end{array}$ & $\begin{array}{l}\text { Present } \\
\text { Effort } \\
\text { (boat } \\
\text { days) }\end{array}$ & CPUE & $\begin{array}{l}\text { Boat days to } \\
\text { increased or } \\
\text { decreased to } \\
\text { achieve MSY }\end{array}$ & $\begin{array}{lr}\begin{array}{l}\text { \% of } \\
\text { creased }\end{array} & \text { in- } \\
\text { decreased } & \\
\text { effort } & \text { to } \\
\text { achieve } & \text { MSY } \\
\end{array}$ & $\begin{array}{l}\text { Optimum } \\
\text { boat days } \\
\text { for exploi- } \\
\text { tation at } \\
\text { MSY } \\
\end{array}$ \\
\hline N. bipunctatus & 2419.15 & 1935.32 & $\begin{array}{l}483.83 \\
\text { (excess) }\end{array}$ & 47552 & 1.25 & $\begin{array}{l}384.60 \\
\text { (excess) }\end{array}$ & $\begin{array}{l}0.80 \\
\text { (decrease) }\end{array}$ & 47167 \\
\hline
\end{tabular}

Table. 5. Average catch effort and CPUE of $N$. bipunctatus landed from Wadge bank, South India.

\begin{tabular}{llllllll}
\hline Month & $\begin{array}{l}\text { Average number } \\
\text { of boats operated }\end{array}$ & $\begin{array}{l}\text { Boat } \\
\text { days }\end{array}$ & $\begin{array}{l}\text { Average } \\
\text { ber landed/boat }\end{array}$ & $\begin{array}{l}\text { Average weight } \\
\text { landed boat(kg) }\end{array}$ & $\begin{array}{l}\text { Estimated total land- } \\
\text { ings in weight (kg) }\end{array}$ & $\begin{array}{l}\text { CPUE } \\
\text { Kg/boat day }\end{array}$ \\
\hline June-2015 & 115 & 2760 & 15 & 16.5 & 45540 & 16.5 \\
July & 123 & 3075 & 20 & 26.5 & 81477 & 26.5 \\
August & 260 & 6760 & 32 & 35.5 & 239980 & 35.5 \\
September & 285 & 7410 & 42 & 56.6 & 419406 & 56.6 \\
October & 230 & 5750 & 35 & 42.5 & 244375 & 42.5 \\
November & 175 & 4025 & 26 & 34.4 & 138460 & 34.4 \\
December & 180 & 4320 & 28 & 39.5 & 1093670 & 39.5 \\
Janaury-2016 & 135 & 3510 & 28 & 32.6 & 114426 & 32.6 \\
February & 120 & 3120 & 26 & 35.8 & 111072 & 35.8 \\
March & 171 & 4275 & 22 & 29.5 & 126112 & 29.5 \\
April & 117 & 3042 & 23 & 28.7 & 87305 & 28.7 \\
May & 105 & 2625 & 15 & 18.2 & 47775 & 18.2 \\
Total & $\mathbf{2 0 1 6}$ & $\mathbf{4 7 5 5 2}$ & $\mathbf{3 1 2}$ & $\mathbf{3 9 6 . 3}$ & $\mathbf{2 4 1 9 . 1 5 2}$ & $\mathbf{3 9 6 . 3}$ \\
\hline
\end{tabular}


Table.6. Exploitation ratio and exploitation status of N. bipunctatus.

\begin{tabular}{lll}
\hline Species & $\mathbf{E}=\mathbf{F} / \mathbf{Z}$ & Exploitation status \\
\hline N. bipunctatus & 0.57 & Moderately Over exploited \\
\hline
\end{tabular}

exploitation ratio of $N$. bipunctatus were 0.57 . The estimated ' $Z$ ' values of $N$. bipunctatus by length converted catch curve method were 2.20 (Fig. 4). Presently the $\mathrm{Z}$ and $\mathrm{M}$ calculated for $N$. biptunctatus was lower when compared to stock of the same species of Thoothukudi waters. It could be inferred fishing mortality was higher compared to natural mortality and same trend was evident by at Thoothukudi waters (Hamsa et al., 1999).

The recruitment pattern of $N$. bipunctatus are shown in Fig. 5. The recruits of were recorded throughout the year with a major peak in October to December minor peak in August. However recruitment was evident round the year confirming a year round spawning of this species. Along Vizhinjam coast $N$. bipunctatus was recruited twice a year with a peak during September to June (Madanmohan and Velayudhan, 1986), However in the present study one major peak season could be observed from October to December and minor one in August at Wadge Bank. The major recruitment season coincides with the coast Southwest monsoon and the minor recruitment season falls in monsoon. The results of the length structured Virtual Population Analysis (VPA) employed to recognize the level of mortality on various length groups of $N$. bipunctatus are shown in Fig.6. The fishing pressure on N. bipunctatus was more in the length group of $24 \mathrm{~cm}$ to $28 \mathrm{~cm}$. Similarly, higher fishing pressure were recorded at the terminal length group for another species of Nemipterids (Murty,1987; Vivekanandan, E.(1991; Joshi, 2010 and Swatipriyankasen et al.,2014)

Stock assessment: The annual catch, total stock and annual stock exploitation rate were estimated for $N$. bipunctatus are presented in Table.3. The MSY, $\mathrm{f}_{\text {msy }}$ and the exploitation ratio estimated for $N$. bipunctatus are given in Table 5. The total stock of $N$. bipunctatus were estimated to be 5625.9348 tonnes with annual catch being 2419.152 tonnes against the exploitation rate of 0.43 (Table 5). The estimated MSY for $N$. bipunctatus were 1089.708 tonnes respectively. The difference between the annual catch and MSY for the $N$. bipunctatus was 384.60 tonnes and the present effort could be decreased to 0.80 with the $f_{m s y}$ as 47167.40 boat days (Table 4). The results of the earlier authors (Murty,1987; Joshi, 2010 and Sen et al,2014) on the stock assessment of nemipterids indicated that the stocks are overexploited along the Kerala coast with the exploitation rate reaching 0.6 to 0.8 . Hence the scientific management for this important resources along the Indian coast of Kerala is needed. Similarly, the current exploitation is being continued with the present $F$, there is every chance for decline in the catch of threadfin breams from the trawling grounds of Ker- ala. Through the drawing of yield isopleths, an idea about the present level of yield per recruit with various possible combination of exploitation rate can be evolved. Yield isopleth is one of the prediction tools in stock assessment studies. By using yield isopleths, one can get an idea about the present level of yield per recruit with various possible combinations of exploitation rate and gear $(\mathrm{L} 50 / \mathrm{L} \infty)$. The yield per recruit for $N$. bipunctatus is shown in Fig.7. The result on yield per recruit for $N$. bipunctatus can be possible to achieve the maximum yield with the exploitation rate and $\mathrm{L} 50 / \mathrm{L} \infty$ of 0.60 and 0.47 . The study infers the cod end mesh size off the trawls of Wadge Bank to be increased to 10 to $25 \mathrm{~mm}$ so as to increase the yield per recruit, the exploitation need to be optimize between 0.45 to 0.5 to get maximum yield per recruit, against the present exploitation ratio of 0.57 (Table 6). The study also suggests eight percent reduction in the present level of effort besides recommending the fitting of square mesh panel the cod end of trawlers.

\section{ACKNOWLEDGEMENTS}

The authors would like to thank the Dean, Fisheries College and Research Institute, Thoothukudi for his encouragement and for providing the necessary facilities to undertake this work.

\section{REFERENCES}

Devaraj, M. and Deepak, G.(1988). Assessment of the stock of the threadfin bream (Nemipterus japonicus) in the northwest continental shelf of India. (Ed.) Mohan Joseph M. The First Indian Fisheries Forum Proceedings. Asian Fisheries Society, Indian Branch, Mangalore. pp 494.

Gayanilo, F.C.Jr., Soriano, M. and Pauly, D.(1988). A draft guide to complete ELEFAN. ICLARM Software Project. pp 2: 65 .

Gulland ,J.A., (1979). Report of the FAO/ IOP workshop on the fishery resource of the Western Indian Ocean South of Equator. FAO.IOFC /DEV.79/45:1-35.

Hamsa, K. M. S., Ameer, H., Mohamad Kasim and Rajapackiam,S.(1994). Length weight relationship of Lutjanusrivulatus off Tuticorin, Gulf of Mannar. Bull. Cent. Mar. Fish. Res. Inst. 47: 128-129.

Harris, A. N. and Poiner, I. R. (1990). By-catch of the Prawn Fishery of Torres Strait; Composition and Partitioning of the discards into components that float of sink. Australian Journal of Marine and Freshwater Research. 41 (1):37-52.

Joshi, K.K. (2005). Biology and population dynamics of Nemipterus mesoprion (Bleeker) off Cochin. Indian J. Fish. 52 (3): 315-322

John, M.E.(1989). Population dynamics and stock estimates of the threadfin bream (Nemipterus japonieus) off Kerala, India. Contributions to Tropical Fish Stock Assessment in India, pp 45-62. (Eds). Venema S C and Van Zalinge N P. Papers prepared by the partidpanu at the FAO/DANIDA/ICAR National follow up training course on fish stock assessment FI: OCP/INT/392/DEN/ 1: pp 157. 
Joshi, K. K.(2010). Population dynamics of NemipterusJaponicus (Blotch) trawling grounds off Cochin. Indian. $J$. fish. 57(1): 7-12.

Madanmohan and Velayudhan, A. K.(1984). A few observations on the taxonomy and biology of Nemipterus delagoae Smith from Vizhinjam. Indian J. Fish. 31:113-121

Murty, V. S. (1983). Estimates of Mortality, population size and yield per recruit of Nemiplerusjaponicus (Bloch) in die trawling grounds, off Kakinada. Indian Journal of Fisheries 30: 2-60.

Murty, V. S. (1984). Observaticns on the fisheriei of threadfin breams (Nemipteridae) and on the biology of Nemiplerusjaponicus (Bloch) from Kakinada. Indian Journal of Fisheries. 31: 1-18.

Murty, V. S. (1987). Further studies on growth and yield per recruit of Nemiplerusjaponicus (Bloch) from the trawling grounds off Kakinada. Indian Journal of Fisheries. 34: $265-76$.

Muthiah, C. and Pillai, S.K.(1979). A new distributional record of N. Delagoae (Smith) from Bombay waters with notes on its biology. J. mar. bio. Assoc. India. 21 (1-2):174-178.

Pauly,D. and Martosubroto, P. (1980). The population dynamics of Nemipterus marginatus(Cuvier \& Val.) off Western Kalimantan, South China Sea. Journal of Fish Biology. 17:263-273

Russell B.C. (1990). Nemipterid fishes of the world
(Threadfin breams, whiptail breams, monocle breams, dwarf monocle breams, and coral breams) Family Nemipteridae. An annotated and illustrated catalogue of nemipterid species known to date. FAO Fish. Syn., 12 (125) (Russell B.C., ed.) Rome: FAO pp 1-149

Sharum, Y. (2002). Demersal Fish Stock Assessment in the Inshore Area of the East Coast of Peninsular Malaysia, (2001). In: Mansor, M.I. (ed.). Thirteenth Trawl Survey of the Coastal Waters off the East Coast of Peninsular Malaysia (April-June 2001). Ministry of Agriculture Malaysia.pp 138

Sparre, P. and S.C. Venema.(1998).Introduction to tropical fish stock assessment, Part 1-manual. FAO Fisheries technical paper. 2: 306-1.

Swatipriyankasen, G.R. Dash, Mohammed Koya K., Sreenath K.R., Suresh Kumar Mojjada, Mahendra Kumar Fofandi, M.S., Zala and Sonia Kumari.(2014). Stock assessment of Japanese threadfin bream, Nemipterus japonicas (Bloch, 1791) from Veraval water. Indian Journal of Geo-Marine Sciences. 43(4):519-527.

Vivekanandan, E. and James, D.B.(1986). Length-weight relationship in four species of threadfin breams from Madras. J. Mar. Biol. Ass. India. 26(1\&2): 132-135.

Vivekanandan, E.(1991). Spawning and growth of three species of thread fin breams off Madras. Indian J. Fish. 38(1): 9-12. 